\title{
TECHNOLOGY AND BUSINESS
}

\section{MIGRATION OF RADIO AND THE MARKET}

\section{Chair: RODRIGO NEVES - General Director Rede Bandeirantes / Campinas}

Representatives of Brazil's main radio stations involved in the migration of AM radio to FM, highlight the model of expected business through integration with the programming on FM, although in eFM (Extended FM). The current scenario of radio broadcasters in the advertising market.Highlights for the preservation of radio with the journalistic content, radio with image, online and hybrid platforms successful cases such as the recovery of the hearing of the Media Wave stations by migration.

\section{- A CASE OF SUCCESS}

Speaker: Roberto Dimas Ribeiro do Amaral - Product Director - Sistema Catarinense de Comunicações Product Director

The presentation highlights the success of Radio Clube de Lages Ltda, of the Sistema Catarinense de Comunicações, the second broadcaster to migrate in Brazil from AM to FM.Management of modeling work, content crystallization - migrant radio - with wide audience recovery in Lages and Region.Proof through audience research. Market and the Challenge!Post migration success with revenue growth. Group broadcasters strengthened and motivated.

- PIONEER MIGRATION

Speaker: Paulo Machado de Carvalho Neto - President of the AESP - the Association of Radio and Television Broadcasters in the State of São Paulo o Jovem Pan: Journalism, the key to success - Social approach and audience polarization / hegemony in $\mathrm{AM}$ and $\mathrm{FM}$ with the same content. Pioneering in the operation of the FM transmitter in the extended range, in a unique test in Brazil in $84.7 \mathrm{MHz}$ homologated by Anatel.

- Speaker: Carlos Rubens Doné - Market Director - Rádio Itatiaia

- Speaker: Ricardo Gandour - News Director CBN 


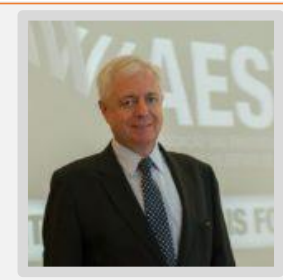

\section{Rodrigo Neves - General Director Rede Bandeirantes / Campinas}

Rodrigo Neves, journalist specializing in radio journalism. Currently holds the position of General manager at Grupo Bandeirantes de Comunicação in the city of Campinas, SP, which consists of four radio stations, a television station and a daily newspaper. From July 2011-July 2015, he was president of the AESP, the Association of Radio and Television Stations in the State of São Paulo, the first industry association in Brazil and the most important regionally speaking, and presently holds the seat as 2nd Member of the Board of the association. He is Regional Vice President Regional of Amcham Campinas, a Member of the Board of the Centro Infantil Boldrini, the charity children's cancer and hematology hospital; SERTESP - the Union of Radio and Television Companies in the State of São Paulo and the Centro Corsini, a highly complex shelter for children and adolescents.

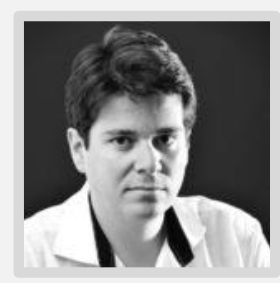

\section{Roberto Dimas Ribeiro do Amaral - Product Director - Sistema Catarinense de Comunicações Product Director}

Roberto Dimas Ribeiro do Amaral is an Electrical Engineer from UFSC and a Business Administrator from UNISUL. Doctor in Sciences and Technologies of Information, by ISCTE-IUL. Product Director of the Sistema Catarinense de Comunicações (SCC), which includes SBT Santa Catarina, radios and telecommunications companies, and is responsible for Engineering, Journalism, Programming, Operation and New Products. He is a member of the Executive Board of ACIL (Commercial and Industrial Association of Lages), SERT (Union of Radio and Television Companies of SC) and ABCOMM / SC (Brazilian Electronic Commerce Association)

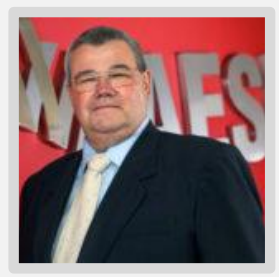

\section{Paulo Machado de Carvalho Neto - President of the AESP - the Association of Radio and Television Broadcasters in the State of São Paulo}

Paulo Machado de Carvalho Neto, aka Paulito, as he is known within the industry, is a business administration graduate, radio commentator and advertising executive, comes from a family with important roots in the means of communication in Brazil. In 1962, when still a lad, Paulito began working at Rádio Record S. A. as an office assistant, although a member of the owner's family. He gradually rose through the ranks, becoming Artistic and Programming Director of Rádio Record A. M., Finance Director, General Manager of Rádio Record, Executive Director for F.M., Executive Director of TV Record de São José do Rio Preto S/A, Executive Director of F.M. Record S/A and Executive Director of TV Record de Franca S/A. In 1990, he took up the position of Executive Director of Record S/A. Besides his functions at the United Broadcasters, Paulito was a member of the board of Fepasa and Assistant Director of the CCESP. From 2000 to 2004, he was President of the Abert- the Brazilian Association of Radio and Television Broadcasters for two consecutive terms of office. He has held several managerial positions in broadcasting entities and ...

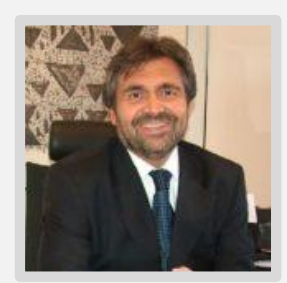

\section{Carlos Rubens Doné - Market Director - Rádio Itatiaia}

In charge of the commercial, marketing and promotions areas, Carlos Rubens dos Santos Doné has worked for Rádio Itatiaia since 1992, after spending 13 years with Rede Globo. With a degree in journalism and advertising from the former FAFI-BH, and a graduate degree in Marketing Management from UNA, Doné also travels around Brazil, giving talks. He was seven-times winner of the Melhores da Comunicação de Minas Gerais (The Best in Communication in Minas Gerais) award offered by the AMP (the Advertising Industry Association in Minas Gerais) and by SinaproMG (the Advertising Agencies Union). Doné he was also the brains behind Itatiaia Rádio Bar and 
Itatiaia no Ponto, a promotions and events agency. For him, the unceasing quest for information and speed of response are the key virtues of a communication professional.

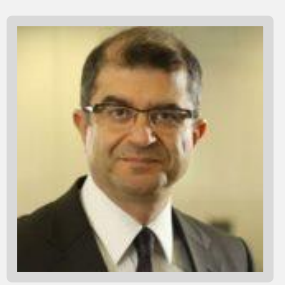

\section{Ricardo Gandour - News Director CBN}

Ricardo Gandour worked for more than 10 years in Grupo Estado. His last position was Director of Content. Previously, he had worked at Grupo Globo as director of Época magazine and Diário de São Paulo newspaper. 